\title{
Cost Analysis of Precast and Cast-in-Place Concrete Construction for Selected Public Buildings in Ghana
}

\author{
Richard Oduro Asamoah, John Solomon Ankrah, Kofi Offei-Nyako, and Ernest Osei Tutu
}

Council for Scientific and Industrial Research, Building and Road Research Institute, Kumasi, Ghana

Correspondence should be addressed to Richard Oduro Asamoah; richardasamoah760@yahoo.com

Received 23 May 2016; Revised 5 August 2016; Accepted 29 September 2016

Academic Editor: Eric Lui

Copyright (C) 2016 Richard Oduro Asamoah et al. This is an open access article distributed under the Creative Commons Attribution License, which permits unrestricted use, distribution, and reproduction in any medium, provided the original work is properly cited.

\begin{abstract}
The construction industry in Ghana is becoming efficient in the area of cost and achieving advance technologies. The effective management of cost enables clients, developers, and facilitators to achieve value for money. Concrete is a major component in every construction project. The use of precast concrete technology has been embraced by the construction industry in Ghana. This study seeks to analyze cost estimating of the structural frame (column and slab) by considering cast-in-place and precast concrete slabs and columns, respectively. Relative importance and Kendall's concordance agreement were used to determine the rankings and agreement of advantages of using precast concrete. The study established that precast concrete slabs were on average $23.22 \%$ cheaper than the cast-in-place concrete elements and precast columns were averagely $21.4 \%$ less than cast-in-place concrete columns. The study established that professionals prefer the use of precast concrete products because of the life cycle cost.
\end{abstract}

\section{Introduction}

Concrete material is the most widely used construction material on earth which comprises about $60 \%$ of the built environment in many developed countries [1]. Concrete has shaped civilization from as far back as the ancient Egypt and the Roman Empires and it is indispensable in the development of infrastructure, industry, and housing. Without concrete the built environment would fail to accommodate our modern and demanding lifestyle [1]. For concrete the basic building materials provide strength, durability, and even elegance far in excess of many of its manufactured competitors [2]. Concrete has a wider range of uses in the construction of commercial buildings, roads, harbours, dams, bridges, electric poles, residential buildings, retaining walls, reservoirs, septic tanks, canals, and a whole lot more [3]. The durability of concrete is of vital importance regarding the life cycle cost of the structure, which includes not only the initial cost of the material and labour but also the cost of maintenance and repair [4]. The durability of concrete is therefore defined as its ability to resist weathering action, chemical attack, abrasion, and other forms of deterioration [5]. Concrete has much higher level of fire resistance than other building materials. It is not combustible and would not produce smoke or fuel the fire [6]. Concrete product can be either precast or in situ concrete. This study seeks to analyze the elemental cost comparison of precast and cast-in-place slabs and columns of some selected public projects in Ghana. The construction industry in Ghana is not familiar to the use of precast technology for beams, walls, foundations, and so forth and the precast columns and slabs are the most common in the Ghanaian construction industry.

\section{Literature Review}

Concrete is a mixture of cement, fine aggregate, coarse aggregate, and water. Concrete must meet the required standard of strength and durability [7]. In Ghana, the use of concrete and reinforced concrete for construction purposes is very common. There are many types of concrete designed to suit a variety of purposes coupled with a range of compositions, finishes, and performance characteristics [8]. This study focuses on the precast and in situ concrete. Precast is defined as a concept that uses standardized structural components produced away from the construction site and 


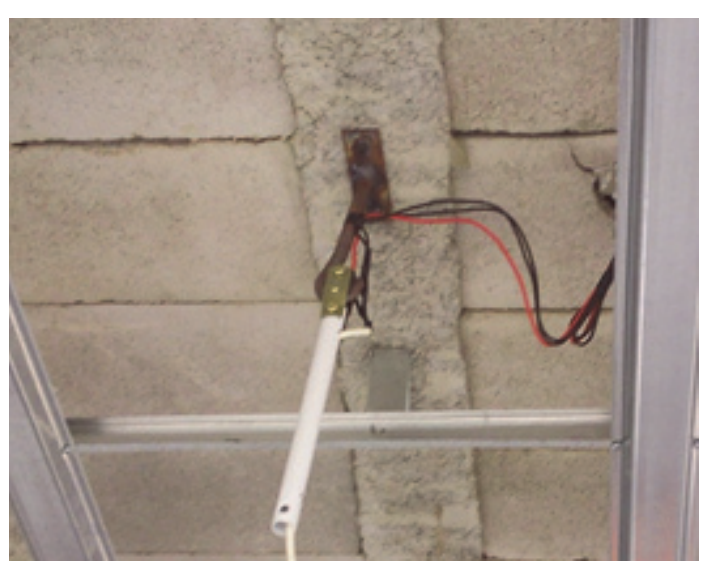

FIGURE 1: Soffit of precast suspended slab showing fun hock and steel ceiling noggins.

the components are transported to the site for assembly $[9,10]$. These components are manufactured by industrial methods based on mass production in order to build a large number of buildings in a short time at low cost [11].

The use of precast concrete has various advantages which include the reduction of the site labours, less wastage, less volume of building materials, and increased environmental and construction site cleanliness. The use of precast products also provides safety at construction site and reduces time of completion in construction [12]. Figure 1 shows how easy it is to fix fun hock and steel ceiling noggins. All these indirectly signify that the precast concrete is much more economical, though the construction cost involves all matters either initially or throughout the building's life [13]. Most concrete buildings are cast-in-place; the wet mix is deposited and formed at the place where the finished concrete is desired, generally referred to as site cast concrete, since the location is usually at a building site [14]. Precast concrete is defined as the process of casting of concrete elements offsite and move them to the actual building site. Concrete for site cast construction is typically brought to the site by concrete, transporting mixer trucks with the large rotating barrels [15]. The mix is prepared at a central batching plant, where controls of the materials may be carefully monitored. However, the transporting to the site, proper mixing in truck, discharging from the truck and depositing in the forms, and handling for placement, finishing, and curing are all subject to the level of responsibility and craft exercised by the people involved [16]. Site conditions in terms of accessibility and weather can be highly critical to the work, requiring extreme measure in some situations to control all the stages in the production process [17]. An element is defined as a part of the building or service which performs the same function in its purest form [18]. One of the most effective tools that Quantity Surveyors use in the planning and design process is the elemental cost plan. Cost of any project is influenced by project location, type of design, size of the building, date of tender, and prevailing market conditions [19]. Elemental cost analysis is the study of costs to client which is given to tenders to determine the probable cost of each element of a building. The purpose of elemental cost is to show the distribution of the cost of a building among its elements in a meaningful term to both clients and design team and by so doing allow the cost of two or more buildings to be compared. However there are other factors that affect elemental cost and these are quantity, quality, and price levels [20]. The theory behind the analysis of building costs per element is that the total cost is a sum of the cost of individual elements such as walls, roofs, foundations, structural frame, sprinkler systems, and lighting [21]. Elements usually perform a given function, regardless of the design specification, construction method, or materials used in the construction of the building. For better tool for analysis elemental cost estimating formats were developed [22]. Elemental cost estimating is one of the methods of approximate estimating which gives a simple and quick quantification of buildings but the method requires significant expertise and judgment in their pricing. This method analyzes the cost of the project on an element by element basis [23]. The study seeks to analyze the comparative cost of structural frame of some selected public buildings in Ghana. The structural frame will include columns and suspended slabs. The precast columns and suspended slabs are mostly used in Ghana. This will inform policy maker in the construction industry on the sensibility of their relation to concrete and infrastructure developments.

\section{Methodology}

The study was a case study of some selected public institutions, which were supervised by CSIR-Building and Road Research Institute. The analysis was based on actual working drawings and bills of quantities of completed and on-going projects. The information for the research was obtained mainly from books, interpersonal interviews, and actual site measurements. Various techniques were adopted to come up with the costs of the structural components being studied. Table 1 shows a list of 13 selected projects which were used for the analysis of the cost of suspended floor slab and column.

The projects were in Ashanti, Greater Accra, and Brong Ahafo regions of Ghana; 7 of the projects were on-going projects, and 6 were completed. Relative Important Index (RII) was used to rank the advantages of using precast concrete from the professionals who were involved in all the selected projects. The RII value indicates the relative significance or importance of one factor compared to other variables in the same category. The RII was calculated using the formula

$$
\text { Relative Important Index }(\mathrm{RII})=\sum \frac{W}{A N},
$$

where $W$ is the weights given to each variable by the respondents, ranging from 1 to $5, A$ is the highest weight (i.e., 5 in the study), and $N$ is the total number of samples.

\section{Results and Discussions}

4.1. Cost Comparative Analysis between Cast-in-Place and Precast Suspended Floor Slabs. The main aim of the study 
TABLE 1: List of selected projects.

\begin{tabular}{lll}
\hline Item & Some selected public projects & \\
\hline 1 & Construction of 8-unit staff bungalow for ST. Joseph College of Education & On-going \\
2 & Construction of 2-storey administration block for Mampong Technical College of Education & On-going \\
3 & Construction of 8-unit staff bungalow and 2 No. 12-seater WC toilet facility for Berekum College of Education & On-going \\
4 & Construction of auditorium block for ST. Monicas College of Education, Mampong & On-going \\
5 & Construction of 3-storey classroom block for Tanoso Community Health Nurses Training School & On-going \\
6 & Completion of 3-storey administration block for Asunafo South District Assembly & On-going \\
7 & Construction of new administration block for CSIR-BRRI & On-going \\
8 & Construction of 2-storey dormitory block for Effiduase Secondary/Commercial School & Completed \\
9 & Construction of 3-storey 12-unit flat for Effiduase Secondary/Commercial School & Completed \\
10 & Construction of the extension of head office block for Minerals Commission, Accra, Ghana & Completed \\
11 & Construction of auditorium for Sunyani Polytechnic & Completed \\
12 & Construction of 18-unit 3-storey model school for Ejisu-Juaben District & Completed \\
13 & Construction of new assembly hall for Effiduase Secondary/Commercial School & \\
\hline
\end{tabular}

was to analyze the cost comparison between cast-in-place and precast concrete of some 13 public buildings in Ghana as indicated in Table 1. The study focused on suspended slabs and columns. The construction industry in Ghana is not familiar with the use of other precast elements like beams, walls, foundations, and so forth, with the exception of precast columns and prestressed beams; it is very challenging to get other precast elements. All the selected projects had a concrete mix proportion of $1: 2: 4$ ratio for both cast-inplace and precast concrete. All columns had 6 numbers of $16 \mathrm{~mm}$ diameter bars at a height of 3 metres, a column width of $450 \mathrm{~mm}$ (the concrete mix proportion is based on weight, use of 4 pounds of coarse aggregate and 2 pounds of sand for every pound of cement). Precast concrete columns were reinforced with 6 numbers of $16 \mathrm{~mm}$ diameter bars $10 \mathrm{~mm}$; stirrups at $200 \mathrm{~mm}$ centres. The analysis for the selected projects was for ground floor columns and first floor suspended slabs. The projects were from 2005 to 2016. Table 2 shows the summary of cost and percentage changes for both cast-in-place and precast suspended concrete floor slabs. Table 2 revealed that, depending on the project size, design considerations, and other related factors, all the projects indicated reduction in cost for the precast concrete suspended slab as compared to the cast-in-place concrete. The highest percent reduction was $35.14 \%$ (construction of new assembly hall for Effiduase Secondary/Commercial School) and the lowest was the construction of auditorium block for St. Monica's College of Education with a percentage reduction of $13.5 \%$. The study revealed an average percentage reduction of $23.22 \%$. The study analyzed the cost comparison between the precast and the cast-in-place concrete using elemental cost analysis of slabs for the 13 selected projects.

\subsection{Cost Comparative Analysis between Cast-in-Place and} Precast Columns. Table 3 revealed that precast concrete columns were on average $21.4 \%$ cheaper than cast-in-place columns. The highest reduction was $24.5 \%$ and the lowest was $18.33 \%$. In Ghana, precast columns are sold in hollow forms,

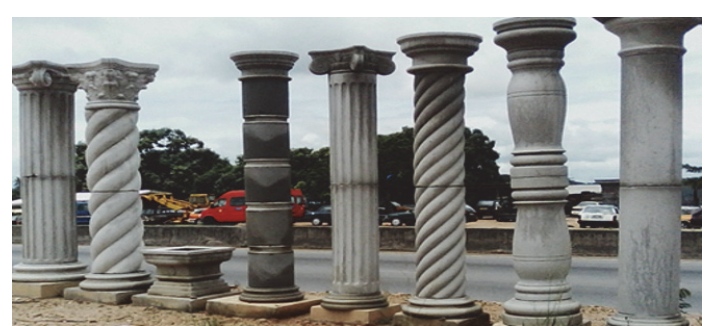

FIGURE 2: Types of precast hollow column.

and the cost of a column depends on the specifications and the type as shown in Figure 2. The main cost variations between cast-in-place and precast columns were the reduction in labour, formwork, and reduction in volume of concrete.

4.3. Comparison of Cast-in-Place and Precast Concrete. The major variations for cost comparison between cast-in-place and precast occur in the cost of formwork, reinforcement, cost of workmanship, and concrete in slabs and columns. Table 4 shows the processes of constructing cast-in-place floor slabs which require formwork for the soffit of slab, formwork for beams, laying reinforcement in slabs, pouring, vibrating concrete, and tampering concrete in place, and all these activities also require workforce and level of precision. But the use of precast will require transporting and assembling of prestressed beams and hollow blocks which requires accuracy. The precast prestressed beams and hollow blocks are self-supported and do not need much formwork as in the case of cast-in-place concrete except for some skeletal props to support the floor when spreading the concrete topping. The reinforcement in precast floor is small as compared to cast-in-place concrete, where reinforcement is required for beams and the slab; hence, the cost is small as compared to cast-in-place floor slab. Precast beams and hollow blocks arrangement serves as the horizontal plate as shown in Figure 1. The concrete in the cast-in-place floor slab is $150 \mathrm{~mm}$ 


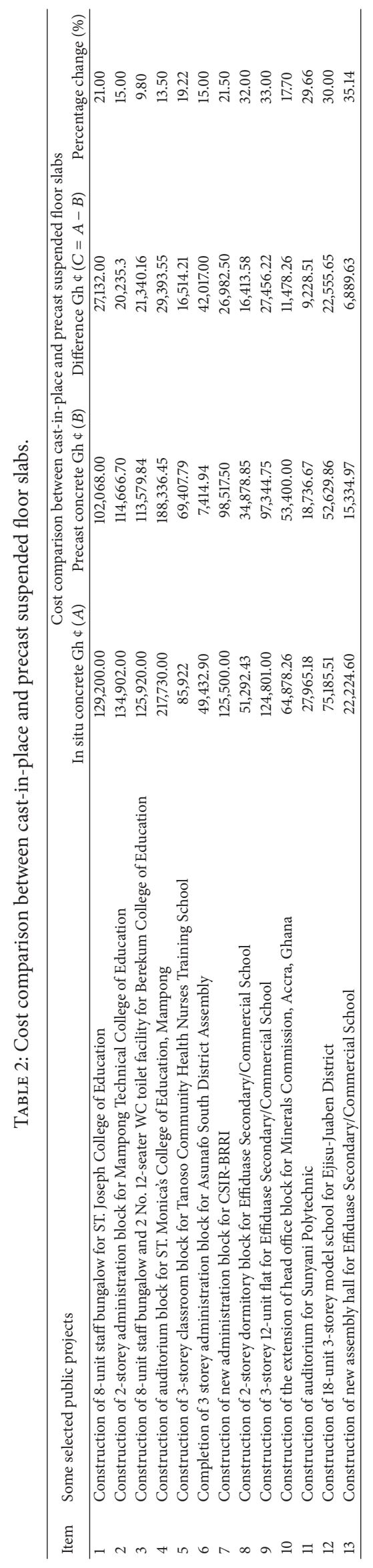




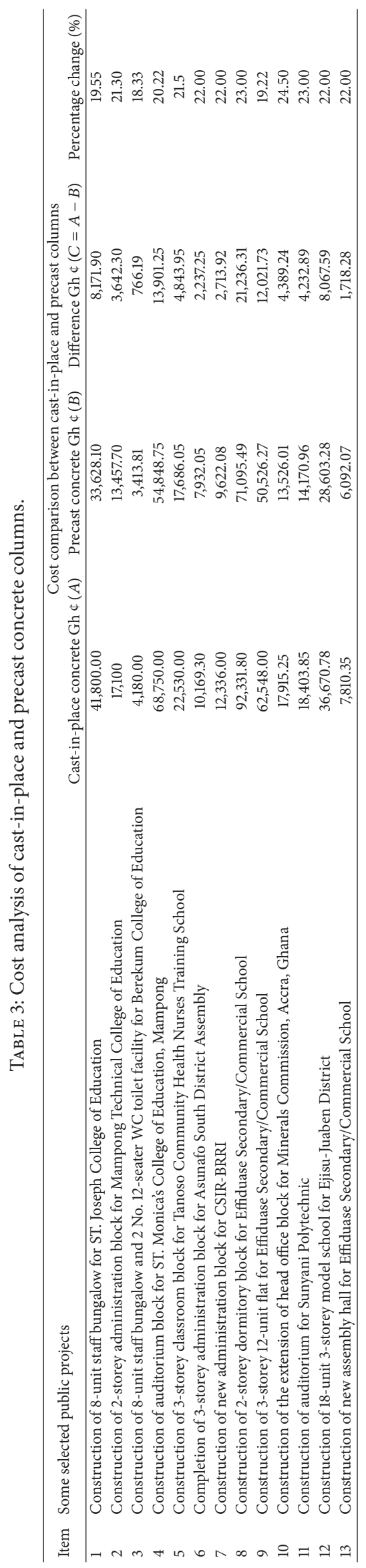




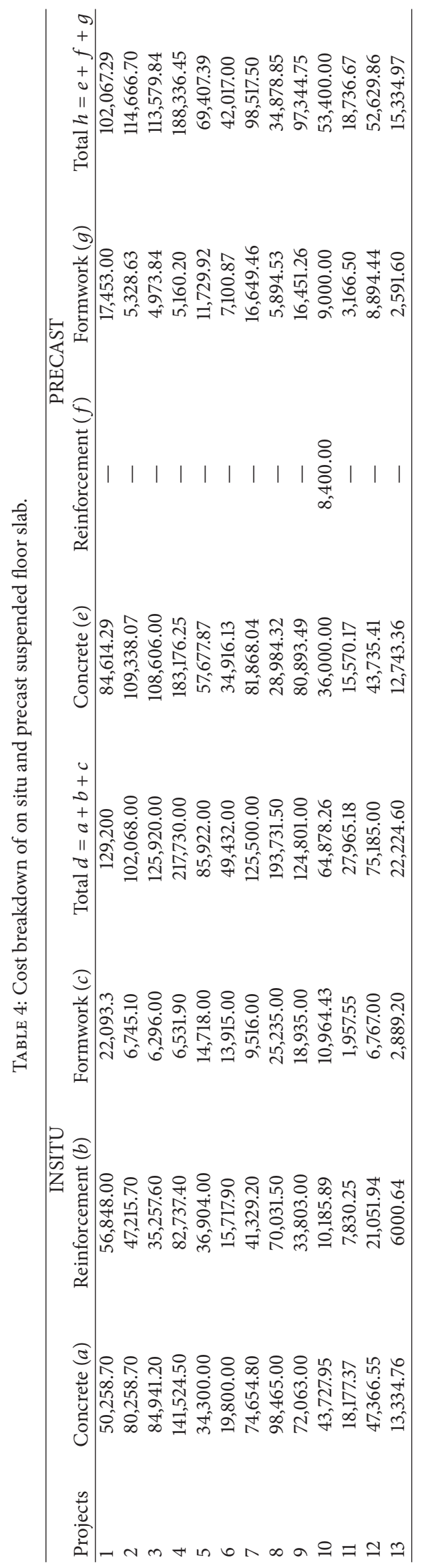


TABLE 5: Professionals opinions on using precast concrete product.

\begin{tabular}{llcccccccccc}
\hline \multirow{2}{*}{ Number } & Advantages & \multicolumn{3}{c}{ Rating } & & \multirow{2}{*}{ Total } & \multirow{2}{*}{$\sum W$} & Mean & RII & Rank \\
& & 1 & 2 & 3 & 4 & 5 & & & & \\
\hline 1 & Low life cycle cost & 0 & 0 & 2 & 42 & 34 & 78 & 344 & 4.4103 & 0.882 & 1 \\
2 & Reduction of on-site waste & 0 & 0 & 2 & 50 & 26 & 78 & 336 & 4.3077 & 0.862 & 2 \\
3 & Speed of construction & 0 & 2 & 6 & 46 & 24 & 78 & 326 & 4.1795 & 0.836 & 3 \\
4 & Quality & 2 & 0 & 10 & 54 & 12 & 78 & 308 & 3.9487 & 0.79 & 4 \\
5 & Durability & 0 & 2 & 16 & 48 & 12 & 78 & 304 & 3.8974 & 0.779 & 5 \\
6 & Dimensional accuracy & 0 & 16 & 14 & 28 & 20 & 78 & 286 & 3.6667 & 0.733 & 6 \\
7 & Reduction of on-site labour & 0 & 14 & 12 & 48 & 4 & 78 & 276 & 3.5385 & 0.708 & 7 \\
8 & Reduction of on-site activity, noise, and disturbance & 0 & 14 & 20 & 34 & 10 & 78 & 274 & 3.5128 & 0.703 & 8 \\
9 & Sandwich panels available for insulation & 6 & 16 & 12 & 26 & 18 & 78 & 268 & 3.4359 & 0.687 & 9 \\
10 & Minimal maintenance & 6 & 16 & 4 & 46 & 6 & 78 & 264 & 3.3846 & 0.677 & 10 \\
11 & Thermal inertia reduces lifetime energy costs & 0 & 14 & 22 & 42 & 0 & 78 & 262 & 3.359 & 0.672 & 11 \\
12 & Large spans available from prestressing & 6 & 26 & 4 & 34 & 8 & 78 & 246 & 3.1538 & 0.631 & 12 \\
13 & Tight tolerances & 4 & 34 & 6 & 28 & 6 & 78 & 232 & 2.9744 & 0.595 & 13 \\
14 & Acoustic insulation & 12 & 36 & 10 & 14 & 6 & 78 & 200 & 2.5641 & 0.513 & 14 \\
\hline
\end{tabular}

Source: Field Survey, 2014.

thick while that in the precast is $50 \mathrm{~mm}$ used as topping for the beam and blocks system to even out the surface. The volume of concrete used is one-third of that used in cast-inplace. The number of workforce required for the processes in cast-in-place concrete is more as compared to precast. Also precast columns serve as formwork; therefore formwork will not be required. Table 4 shows the summary of cost break down of selected projects. The cost breakdown for both castin-place and precast includes all labour components. Except project 10 (construction of the extension of head office block for Minerals Commission, Accra, Ghana) where the floor slab was reinforced with additional $10 \mathrm{~mm}$ diameter bars all others were not reinforced. Data were obtained from bills of quantities and actual site visit measurement of respective projects. The precast concrete cost includes transportation and assembling on site.

4.4. Determining Degree of Agreement on the Advantages of Using Precast Concrete among Building Professionals. The study also sought the opinions of building professionals (Civil Engineers, Quantity Surveyors, and Architects) who worked on the selected projects about the advantages of using precast concrete. Table 5 revealed the views from the professionals. Using Relative Important Index, Table 5 revealed that professionals consider low life cycle cost the main advantage of using precast concrete products and space for acoustic insulation as the least.

Based on the important indices, the advantages of using precast concrete were ranked and the agreement between the sampled building professionals was determined by the use of Kendall's concordance analysis. Kendall's concordance coefficient, which measures the degree of agreement among sets of ranking, is expressed as $k$ :

$$
W=\frac{\left[\left(R_{I}-R\right)^{2}\right]}{\left[n\left(n^{2}-1\right) / 12\right]},
$$

where $k$ is the number of sets of ranking (e.g., the number of judgments), $n$ is the number of aspects of a problem or factors being ranked, $R$ is average of the ranks assigned to the $n$th aspect of the problem, $n\left(n^{2}-1\right) / 12$ is the maximum possible squared deviation, that is, the numerator which will occur if there were perfect agreements among $k$ sets of ranks, and the average rankings were $1,2,3, \ldots, n . R_{I}$ is the rank assigned by an individual judge to one aspect of the problem posed. The value of $W$ ranges from 0 to 1 regardless of the number of rankings. A high value of $W$ indicates a high degree of agreement between the set of rankings. The significance of $W$ was tested using chi-square distribution. The test was based on the null hypothesis $H_{0}=$ the $k$ set of rankings were unrelated and the alternative hypothesis $H_{1}=$ the $k$ set of rankings were related. The observed chi-square value is calculated using $\lambda^{2}=k(n-1) W$, where $k$, $n$, and $W$ are as previously defined. The critical chi-square value is read from the statistical table at $(k-1)$ degrees of freedom. Where the calculated chi-square value exceeds the critical value (that read from tables), the null hypothesis is rejected and the alternative is accepted. A high significant value of $W$ could be interpreted as meaning that $k$ respondents to a question are applying essentially the same standards in rating the $n$th aspect of a problem under study. For the purpose of interpretation of data, a rating of 1-3 was perceived to be very important, 4-7 important, 8-11 marginally important, and 12-14 not important. Table 6 shows agreement by professions on the advantages of using precast concrete

$$
\begin{gathered}
\text { Grand mean } \check{R}=\sum_{i=1}^{n} R_{1}=2.36, \\
\sum\left(R_{1}-\check{R}\right)^{2}=11.34,
\end{gathered}
$$

where $R_{1}$ is the mean of ranking and " $n$ " is the number of advantages being ranked. $W$ is coefficient of concordance, 


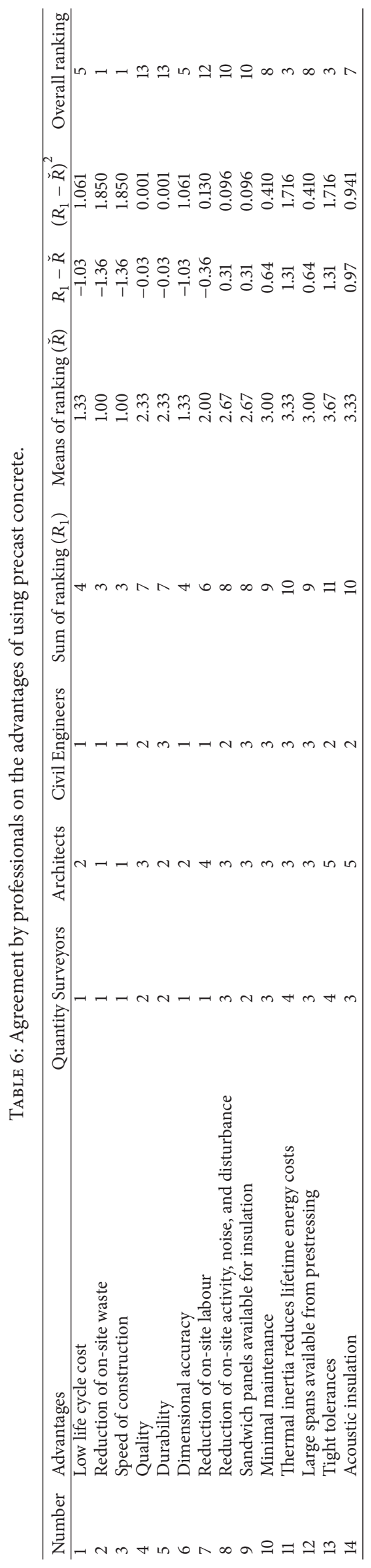


and building professionals (Quantity Surveyors, Architects, and Civil Engineers) are as follows $R=R_{I}$

$$
\begin{aligned}
& k=\text { groupings } \\
& W=\left[\left(R_{I}-\check{R}\right)^{2}\right] /\left[n\left(n^{2}-1\right) / 12\right] \\
& i=1 \\
& n=\text { number of factors ranked }=14 \\
& n\left(n^{2}-1\right) / 12=14\left(14^{2}-1\right) / 12=227.5 \\
& W=11.34 / 227.5=0.050
\end{aligned}
$$

Testing 95\% significance level for $W$, the null hypothesis $\left(H_{0}=\right.$ set of ranking by Quantity Surveyors, Architects, and Civil Engineers) is unrelated. The alternative $H_{1}$ are set of rankings that are related. $\lambda^{2}=k(n-1) W$, where $k$ is the number of groups being compared which in this case $=3$ (i.e., the Quantity Surveyors, Architects, and Civil Engineers being compared). $\lambda^{2}=3(14-1) 0.050=1.95$. From the chi-square distribution tables, the critical value $\lambda_{0.955}^{2}=1.95$ since the observed $\lambda^{2}$ value $=11.070$ is greater than 1.95; the null hypothesis $H_{0}$ is rejected; and the alternative hypothesis $H_{1}$ that the set of rankings by the above groups are related is accepted. This shows that there is high degree of agreement between Quantity Surveyors, Architects, and Civil Engineers on the advantages of using precast concrete suspended slabs and columns. The Kendall's concordance also identified reduction of on-site waste and speed of construction as the main advantages of using precast concrete.

\section{Conclusions}

The study revealed that, on average, the precast concrete slabs were $23.22 \%$ cheaper than cast-in-place concrete construction and precast columns were $21.4 \%$ cheaper than cast-inplace concrete construction, especially for large scale production. The study also revealed that the Ghanaian construction industry have not been using precast beams. Construction professionals prefer the use of precast concrete construction mainly because of low life cycle cost, reduction of on-site waste, speed of construction, and quality of work done. The study also revealed that there is high degree of agreement between Quantity Surveyors, Architects, and Civil Engineers on the advantages of using precast concrete suspended slabs and columns. The Kendall concordance identified reduction of on-site waste and speed of construction as the main advantages of using precast concrete. Prestressed beams and block precast slabs can be embraced as ground floor concrete slabs for new building constructions located in areas where the water table is high to avoid hardcore filling which aids rising damp. The continuous study of elemental cost planning in Ghana will help in the establishment of accurate initial project budget and the maintenance of that budget during the design development and documentation phases.

\section{Competing Interests}

The authors declare that there is no conflict of interests regarding the publication of this paper.

\section{Acknowledgments}

The authors would like to show their utmost gratitude to Miss Olivia Abanyo and Miss Anna Frema Bonsu for their secretarial support and Mr. Philip Bannor.

\section{References}

[1] CCANZ, 2014-15, Annual Report, http://www.ccanz.org.nz/.

[2] N. William, Usability of textile reinforced concrete: structural performance, durability and sustainability [Thesis for the Degree of Doctor of Philosophy], 2015.

[3] M. D. Rahim, S. Mohd, and H. N. Azam, "Construction cost comparison between conventional and formwork system for condominium project," International Journal of Advanced Studies in Computer Science and Engineering, vol. 2, no. 5, pp. 19-25, 2013.

[4] A. Ashworth, Cost Studies of Building, Pearson Prentice Hall, London, UK, 5th edition, 2010.

[5] T. K. Chan, "Comparison of precast construction costs-case study in Australia and Malaysia," in Proceedings of the 27th Annual ARCOM Conference, C. Egbu and E. C. W. Lou, Eds., pp. 3-12, Association of Researchers in Construction Management, Bristol, UK, September 2011.

[6] G. M. E. Cooke, "Behaviour of precast concrete floor slabs exposed to standardised fires," Fire Safety Journal, vol. 36, no. 5, pp. 459-475, 2001.

[7] R. Chudley and R. Greeno, Building Construction Handbook, Elsevier, Amsterdam, Netherlands, 7th edition, 2005.

[8] G. T. Williams, "Basic facts about concrete-design and constituents," Structural Survey, vol. 1, no. 1, pp. 53-57, 1983.

[9] G. Cudney, "Precast VS. Cast-in-Place-How do They Compare?” http://www.carlwalker.com/wp-content/uploads/ 2012/ 10 /precast_vs_cast-in-place.

[10] V. O. Oparebea, Comparative cost analysis of precast and in situ concrete floor slabs in Ghana [M.S. thesis], 2015.

[11] E. A. A. Henin, Efficient precast/prestressed floor system for building construction [Degree of Doctor of Philosophy], The Faculty of the Graduate College at the University of Nebraska in Partial Fulfillment of Requirements, 2012.

[12] F. Giussani and F. Mola, "Precast and cast in situ slab system for residential buildings," in Proceedings of the 31st Conference on Our World in Concrete and Structure, Singapore, August 2006.

[13] W. H. Mosely, J. H. Bungey, and R. Husle, Reinforce Concrete Design, Palgrave, New York, NY, USA, 5th edition, 1999.

[14] N. Dineshkumar and P. Kathirvel, "Comparative study on prefabrication construction with cast in-situ construction of residential buildings," International Journal of Innovative Science, Engineering \& Technology (IJISET), vol. 2, no. 4, 2015.

[15] T. Vaishali and A. Wagmare, "A study of cost comparison of precast concrete vs. cast-in-place," International Journal on Recent and Innovation Trends in Computing and Communication, vol. 3, no. 11, pp. 6235-6238, 2015.

[16] M. J. Madan, Precast Concrete Construction, Survey Institute, West Bengal, India, 2012.

[17] C. K. McCormac and R. H. Brown, Design of Reinforced Concrete, John Wiley \& Sons, 9th edition, 2014.

[18] Africa Association of Quantity Surveyors, Africa Association of Quantity Sureyors, Guide to Elemental Cost Estimating and Analysis of Building Works, Murray and Roberts, Skeen Blvd, South Africa, 2013, http://www.murrob.com/index.asp. 
[19] E. Osei-Tutu and T. Adjei-Kumi, "An evaluation of housing cost trends in Ghana for the period 1991-2008," in Proceedings of the National Housing Conference, CSIR- Building and Road Research Institute, Kumasi and Ghana Institute of Architects, Accra, Ghana, October 2009.

[20] E. Lau and K. S. Yam, "A study of the economic value of highrise office buildings in China strategic integration of surveying services," in Proceedings of the FIG Working Week 2007, Hong Kong, May 2007.

[21] A. Kereshmeh and C. M. Eastman, "A comparison of construction classification systems used for classifying building product models," in Proceedings of the 52nd ASC Annual International Conference Proceedings, Associated Schools of Construction, Georgia Institute of Technology Atlanta, Atlanta, Georgia, 2016.

[22] R. Flanagan and B. Tate, Cost Control in Building Design, Blackwell, Great Britain, UK, 1st edition, 1997.

[23] S. O. Dosumu and O. A. Adenugo, "Assessment of cost variation in solid and hollow floor construction in Lagos State," Journal of Design and Built Environment, vol. 13, no. 1, 2013. 


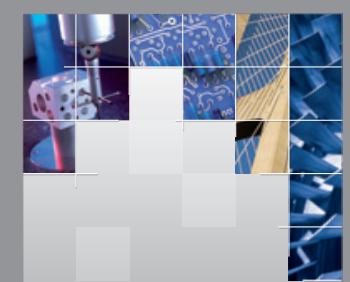

\section{Enfincering}
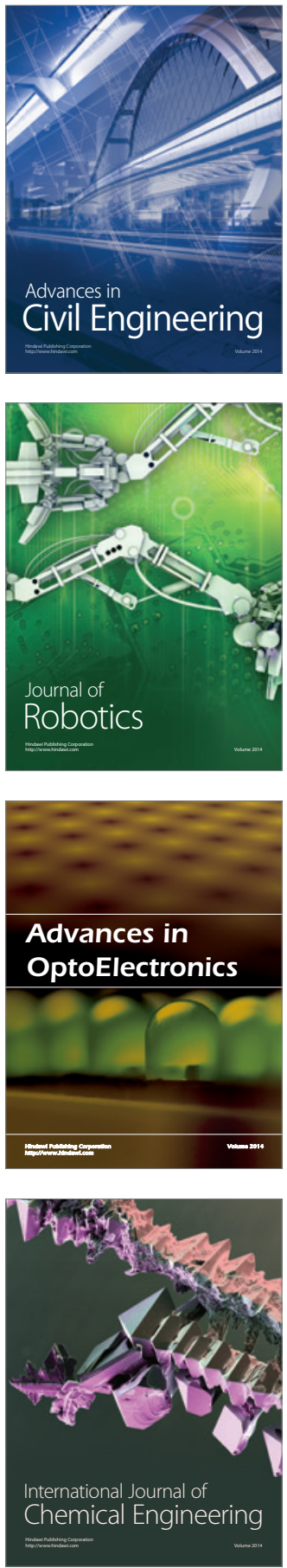

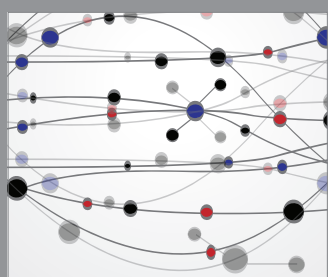

The Scientific World Journal

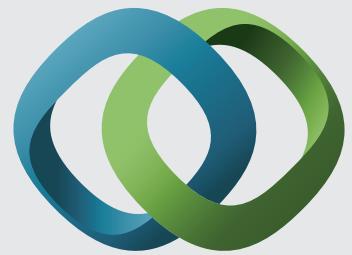

\section{Hindawi}

Submit your manuscripts at

http://www.hindawi.com
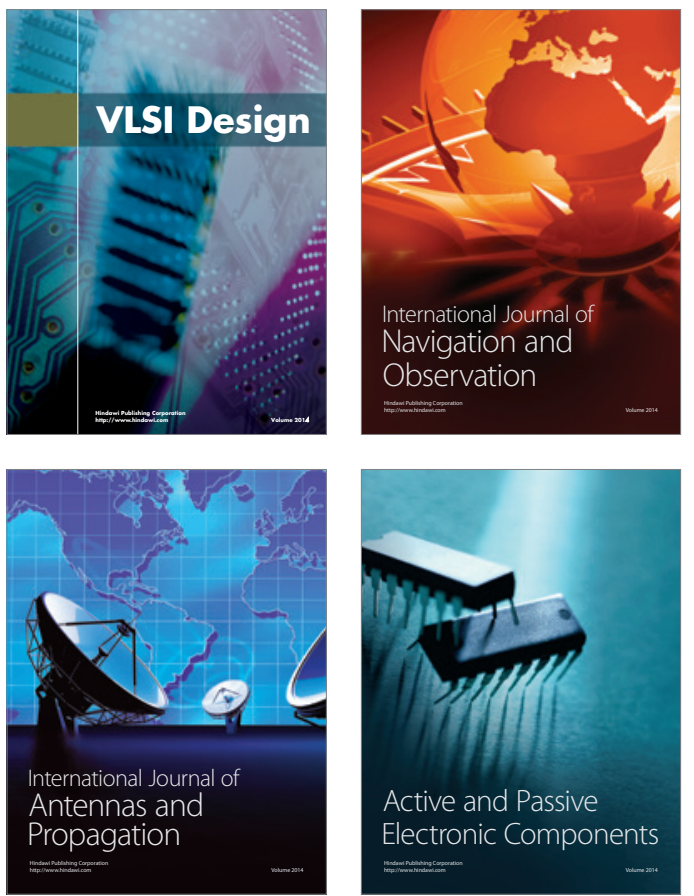
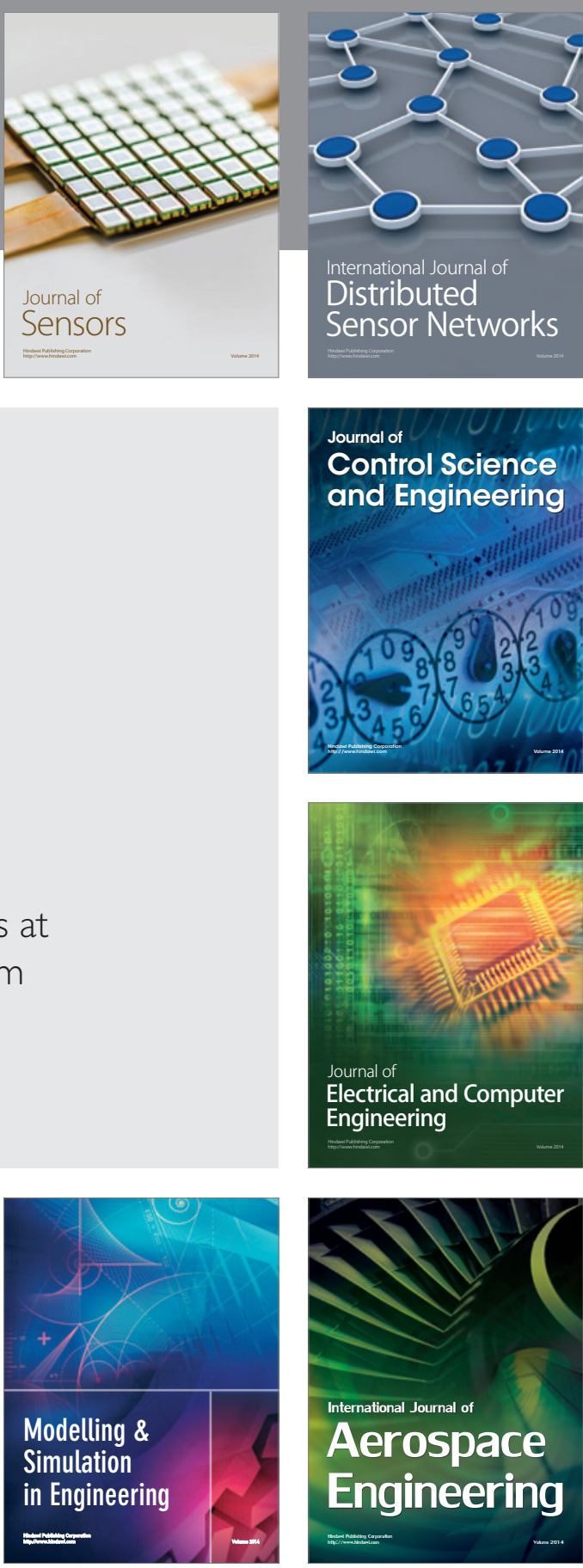

International Journal of

Distributed

Sensor Networks

Journal of

Control Science

and Engineering
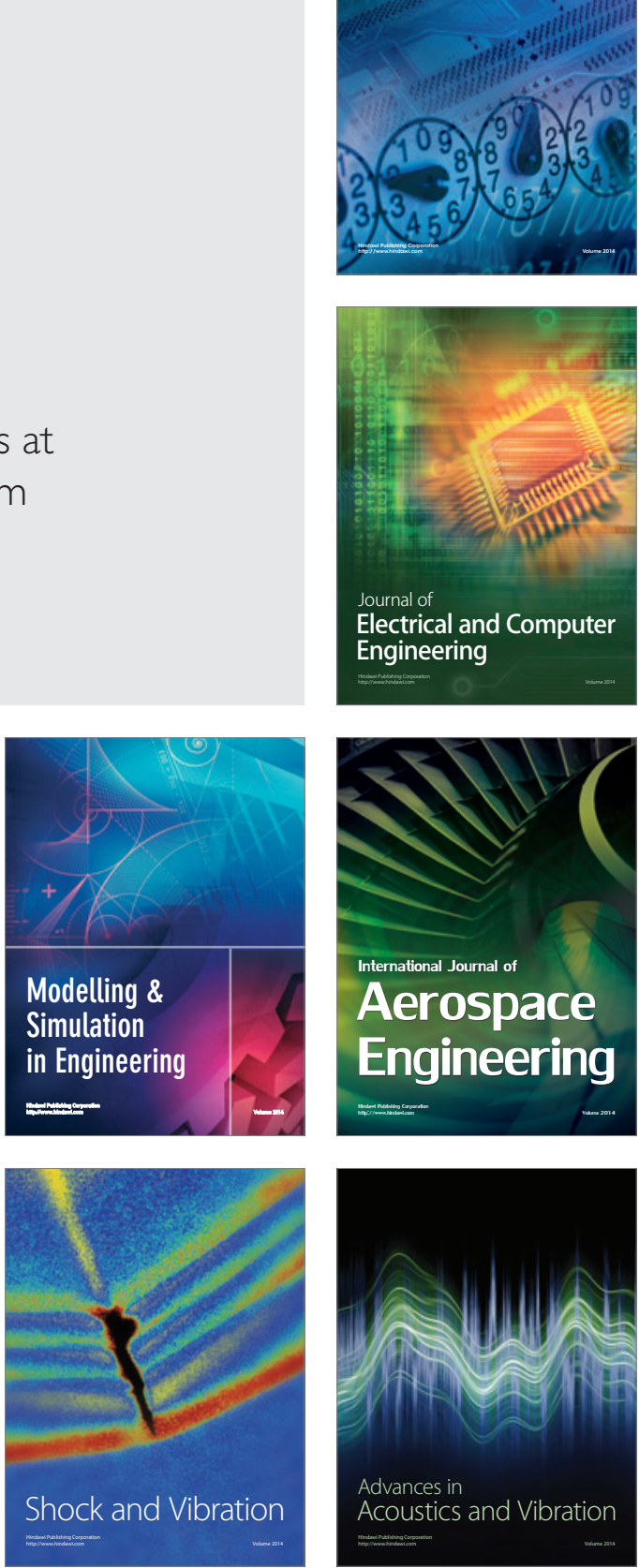